\title{
Determinants of Banks Profitability: Case of Vietnam Listed Commercial Banks
}

\author{
Linh Hoai Do, Lieu Hong Le, and Dan Nguyen Linh Le
}

\section{ABSTRACT}

The authors aim at investigating factors impacting the profitability of Vietnamese Listed Commercial Banks during the period of 2011-2020. Through the Panel Tobit model, the study figured out that the CIR (Cost to Income) has the inverse relationship with the profitability while LDR (Loans to Deposits) positively correlates to the profitability. Based on findings, some recommendations were proposed to enhance the profitability of Vietnamese Commercial Banks in the future.

Keywords: Listed Banks, NIM, Profitability, ROA, ROE, Vietnam.

\author{
Submitted : November 17, 2021 \\ Published : December 09, 2021 \\ ISSN: $2507-1076$ \\ DOI: $10.24018 / \mathrm{ejbmr} .2021 .6 .6 .1171$ \\ Linh. H. Do \\ National Economics University, Vietnam \\ (e-mail: linhdh@neu.edu.vn) \\ Lieu. H. Le \\ National Economics University, Vietnam. \\ (e-mail: lehonglieucva@gmail.com) \\ Dan. N. L. Le \\ National Economics University, Vietnam. \\ (e-mail: linhdan.03112000@gmail.com) \\ *Corresponding Author
}

\section{INTRODUCTION}

The banking industry, playing a key role in the country's development, is regarded as the economy's backbone, and also is severely affected by crises. To avoid bad consequences, the Vietnamese government enacted Decision number 254 of Credit Institutions System Restructuring in 2011, aiming to stabilize the banking system activities and to develop the domestic economy. After that year, all of the bank's performance indexes have been considered seriously, involving the ratio of Profitability of commercial banks. Evaluating such statistics helps experts, shareholders, managers, and policy makers plan and execute appropriate policies.

Regarding professors and experts in the financial field, three indicators including Return on Assets (ROA), Return on Equity (ROE), and Net Interest Margin (NIM) are the most typical when estimating the Profitability of banks. Hence, studying factors influencing such indicators supports the bank's owner to enhance the bank's performance, thereby increasing profits and reducing risks.

For that reason, understanding the factors affecting Profitability of banks is very necessary, the paper chooses the topic "Determinants of Banks Profitability: Case of Vietnam Listed Commercial Banks" to study.

\section{LITERATURE REVIEW}

One of the study topics that has piqued the interest of not only academics but also shareholders, managers, and management body authorities is analyzing the profitability of a commercial bank and finding the factors that influence it. There are several approaches to measuring commercial bank performance, such as using analytical limit operation methods or selecting evaluation results for each aspect such as profitability, level of risk, management ability, and competitiveness; however, the authors chose a method based on bank profitability. Profit maximization is probably one of the most commonly recognized aims for all organizations; as a result, assessing performance in commercial banks includes comparing each bank's achieved profit level to its intended profit level. Evaluating commercial bank profitability entails determining ways to generate profit that is less or higher than that of other commercial banks. If one bank has a higher profit margin than others, it may not be desirable if that bank takes on additional risk rather than improving asset quality or cost management. As a result, in addition to considering a bank's profitability, we must also examine the level of risk that it confronts. In order to ensure financial stability, bank profitability must be monitored not only by the bank but also by the regulatory authorities.

\section{A. The Macroeconomics Factors}

\section{1) GDP growth rate (GDP)}

GDP growth exemplifies the signification of economic prosperity in explaining profitability. The profitability of banks is heavily dependent on the capital demand of individuals and corporations in the economy. Banks will have more chances to create profit and expand profitability in case of high-growth economy. As a result, the influence of economic growth on banks' profitability has become increasingly apparent. This article expects a positive relation between GDP growth rate and bank profitability, similar to Pasiouras and Kosmidou's findings (2007).

\section{2) Inflation (INF)}

Undoubtedly, inflation plays a crucial role in the bank's 
profitability due to its dramatic impact on the interest rate. A higher inflation rate means a higher interest rate on loans, and consequently greater bank profitability. Increasing interest rate, on the other hand, may raise the payback loan's risk since it damages borrowers' finance, threatens their liquidity and limits their capacity to cover loans (Pervan, Pelivan \& Arnerić, 2015). For that reason, this article does not anticipate a positive link between inflation and Vietnamese bank profitability.

\section{3) Interest rate (LIBOR)}

The interest rate is another element influencing the bank's profitability. It shows that there is a favourable relationship between interest rate and profitability. The increase of interest rates on loans will bring profits for banks. Following this, credit risk will happen that affects customers. Thus, LIBOR is a factor needed to consider when calculating profitability.

\section{B. Internal Financial Criteria of Banks}

\section{1) Credit risk (NPL and LDR)}

Credit risk is the most significant business for most Vietnamese banks, accounting for the majority of profits. As a result, one of the most important elements determining commercial bank profitability is effectively managing lending portfolios. Banks will perform poorly if their assets are of poor quality, as the increased costs of setting up reserves would have a detrimental influence on their profitability. Therefore, this association is likely to be negative.

\section{2) Liquidity risk (CDA and LSI)}

Aside from credit risk, liquidity risk is a common risk in the commercial banking industry. Liquidity risk refers to the losses that banks experience as a result of failing to meet withdrawal demands at a fair price. Past occurrences, such as the 2008 and 2011 liquidity crises and deposit interest rate climbing in the banking system, suggested that Vietnam commercial banks were susceptible to liquidity risk.

Several studies claim banks that hold more liquid assets tend to have a lower profit (Sharma, Gounder \& Xiang, 2013). Given the low return relative to other assets, more funds invested in cash or cash equivalents tend to reduce liquidity premium in net interest margin. The expected bankruptcy cost hypothesis, however, predicts that an increase in the relative liquid assets holdings of banks decreases its probability of default - thus, improving bank profits (Bordeleau \& Graham 2010; Bourke 1989). In the case of Vietnam, Le (2017) suggests that a higher fraction of liquid assets improves bank margins as banks compensate extra costs related to holding liquid assets by charging higher margins. Following the literature, Vietnamese banks with lower liquidity risk are expected to have greater profitability.

\section{3) Capital structure (CAP and PE)}

Capital structure was defined by using the equity to total assets ratio. Previous literature found mixed results about the relationship between capital ownership and the performance of a bank. Berger et al. (1995) tested the hypotheses of information and the hypotheses of default cost, showing that the high proportion of equity to total assets will increase operational efficiency due to information problems and the reduction of financial distress costs. However, according to the theory of the balance between risk and returns, the high ratio of capital to assets means lower profitability. A high ratio of capital to assets reduces capital risk, therefore reduces the yield requirements from the investors. Moreover, more equity also leads to the reduction of profit after tax as a consequence of the tax shield decreasing. Thus, this relationship may be positive (+) or negative (-).

\section{4) Bank size (SCALE)}

Because of economies of scale, the size of commercial banks influences their competitive position as well as their ability to expand potential and profit. A bank's total assets represent its size. This research uses the normal logarithm of total assets to lessen the skewness of asset distributions. This variable denotes the benefits of cost savings owing to economies of scale. According to studies by Molyneux and Thorton (1992), Bikker and $\mathrm{Hu}$ (2002), Boyd and Runkle (2000), and Athanasoglou (2008), differences in cost as a result of economies of scale may generate a positive relationship between size and profitability of banks. However, too much size may have a detrimental influence on profitability due to inadequate asset management. Hence, the relation might be positive or negative.

\section{5) Efficiency $(C I R)$}

This is the factor used to assess the bank's performance. It revealed that what banks can do and how much income they can earn with the costs. The higher this rating, the more ineffectual the banks' activities, and the lessened their earnings. This study anticipates a negative association with this variable.

\section{6) Ownership structure (OWN)}

Commercial banks' ownership structure reflects the share capital participation of the government. It has an impact on the company environment, management protocols, operating procedures, business plans, economic integration, and other elements that might affect commercial banks' capacity to profit. The research collected the state ownership rate of banks in the data table (STATE variables). According to Marcia et al. (2010), state-owned banks were even less profitable than privately held banks. In the contrary, Kosak and Cok (2008) investigated banking systems in Eastern European nations, concluding that ownership structure had no effect on bank ROA. In order to test the hypotheses, the study involved a dummy variable of government ownership (Down1). Down1 has a value of 1 if the bank is owned by the government, and 0 otherwise. In Vietnam, state-owned banks are controlled by strict policies such as capital limit, credit limit, customer range, etc rather than privately-owned banks. Hence, the research expects the adverse influence of the state on bank profitability.

\section{7) Profitability (ROA, ROE, and NIM)}

In most studies of commercial bank profitability worldwide, the proxy for profitability is commonly ROE (Goddard, 2014) or ROA (Athanasoglou, 2008). In addition, Kun (1999) analyzed NIM to assess bank performance. The most basic ratio utilized in bank profitability studies is ROA standing for return on total assets (such as the study by Patsiouras, 2007, Goddard, 2004). The return on assets (ROA) illustrated the value of assets and more crucially, depicts the abilities of the top executives when exploiting financial resources to generate profits (Hassan, 2003). ROA 
is impacted by economic circumstances that the bank cannot dictate and is determined by the bank's management planning. Rivard (1997) proposed that the return on assets (ROA) is the most accurate predictor of a bank's profitability. Furthermore, ROA is the most crucial indicator of a bank's capacity to earn income from its total assets. However, there are several shortcomings when using ROA, such as the fact that it ignores off-balance-sheet businesses whose profit was progressive with the bank's profit, meanwhile, the numerator did not include those elements.

The capacity to make profits and add value for shareholders is reflected by the return on equity (ROE). It is seen as the crucial indices when evaluating the profitability of commercial banks. The reason why ROE is valuable is that the ultimate goal of commercial banks is typically to exaggerate the net value of assets. Hence, the shareholders can gain more added value.

Besides, other experimental evidence has proposed that NIM (Net Interest Margin) be used to determine commercial bank profitability. This was due to the fact that net interest income accounted for the majority of commercial banks' revenues. As a result, the ROA and ROE of a bank with a large net interest margin were generally greater than those of other banks. This study applied all three variables ROA, ROE, and NIM as dependent variables as proxies for bank profitability, taking into account the benefits and drawbacks of each.

\section{RESEARCH METHODOLOGY}

\section{A. Data Collection}

The financial data utilized in this study originated from the annual financial statements of 20 commercial banks, as well as income statements from Vietnam banks collected by Vietstock company. In addition, we obtained data on macroeconomic parameters (GDP growth, inflation rate, and LIBOR) from the World Bank and IMF.

\section{B. Econometric Model}

Other authors' prior studies frequently employed FEM, REM, or OLS pooled models to identify the factors influencing Profitability (ROA, ROE, NIM). Nevertheless, applying the Panel Tobit Model (FEM, REM) is the most sensible approach since it has numerous advantages, including enhancing the number of observations, partially resolving multicollinearity, and also being capable of answering lots of crucial questions that cross-sectional or time series data set cannot. This even enables the research to examine the problems of heterogeneity, the uncertainty of each bank in the data sample. Consequently, we opted to employ the Panel Tobit Model rather than OLS.

\section{Panel Tobit Model}

It is unappealing to assume that $\mathrm{C}_{i}$ and $\mathrm{X}_{i t}$ are independent. We can use the Mundlak-Chamberlain method and define $C_{i}$ as a function of observables, for instance:

$$
c_{i}=\psi+\bar{x}_{i} \xi+a_{i}
$$

This means rewriting the panel Tobit as:

$$
\begin{gathered}
y_{i t}=\max \left(0, x_{i t} \beta+\psi+\bar{x}_{i} \xi+a_{i}+u_{i t}\right) \\
u_{i t} \mid x_{i t}, a_{i} \sim \operatorname{Normal}\left(0, \sigma_{u}^{2}\right)
\end{gathered}
$$

We cannot control for $\mathrm{C}_{i}$ using a dummy variable method (incidental parameters problem), and no Tobit model equivalent to the "fixed effects" logit exists. As a result, we analyze the Tobit estimator with random effects.

\section{Empirical model}

The study model used to investigate Profitability in Vietnam is as follows:

$$
\begin{gathered}
\text { PROFIT }_{i t}=\beta_{0}+\beta_{1} \mathrm{NPL}_{i t}+\beta_{2} \mathrm{LDR}_{i t}+\beta_{3} \mathrm{CDA}_{i t}+\beta_{4} \mathrm{LSI}_{i t}+ \\
\beta_{5} \mathrm{CAP}_{i t}+\beta_{6} \mathrm{PE}_{i t}+\beta_{7} \ln (\mathrm{SCALE})_{i t}+\beta_{8} \mathrm{CIR}_{i t}+ \\
\beta_{9} \text { Down }_{i t}+\beta_{10} \mathrm{GDP}_{t}+\beta_{11} \mathrm{INF}_{t}+\beta_{12} \mathrm{LIBOR}_{t}+\varepsilon_{i t}
\end{gathered}
$$

where

PROFIT $_{i t}$ represented dependent variables (ROA, ROE, and NIM) of the bank $i$ at time $t$.

$\mathrm{NPL}_{i t}$ is the Non-performing Loans ratio of bank $\mathrm{i}$ at time $\mathrm{t}$. $\mathrm{LDR}_{i t}$ is the Loans to Deposits ratio of bank $\mathrm{i}$ at time $\mathrm{t}$.

$\mathrm{CDA}_{i t}$ is the ratio of Cash and Due held at other depository institutions to Assets of bank $i$ at time t.

$\mathrm{LSI}_{i t}$ is the Liquidity Stock index of bank $\mathrm{i}$ at time $\mathrm{t}$.

$\mathrm{CAP}_{i t}$ is the Capital ratio of bank $\mathrm{i}$ at time $\mathrm{t}$.

$\mathrm{PE}_{i t}$ is the Price to Earnings ratio of bank i at time $\mathrm{t}$.

$\ln (\text { SCALE })_{i t}$ is the logarithm of total Assets of bank $i$ at time t.

$\mathrm{CIR}_{i t}$ is the Cost to Income ratio of bank $\mathrm{i}$ at time $\mathrm{t}$.

Down $1_{i t}$ is the dummy variable, referring to the Ownership structure of bank $i$ at time $t$ (Down $1=0$ if bank is State's own,

\begin{tabular}{|c|c|c|c|}
\hline Variables & Symbol & Description & Expectation \\
\hline \multirow{3}{*}{ Profitability } & ROA & $\begin{array}{c}\text { Net Income/Average return on } \\
\text { assets }\end{array}$ & \\
\hline & ROE & $\begin{array}{c}\text { Net Income/ Average return on } \\
\text { equity }\end{array}$ & \\
\hline & NIM & $\begin{array}{l}\text { Net Interest income/Average } \\
\text { earning assets }\end{array}$ & \\
\hline \multirow{2}{*}{ Credit risk } & NPL & Total Bad debt/Total Loans & - \\
\hline & LDR & Total Loans/Total Deposits & - \\
\hline \multirow{2}{*}{$\begin{array}{l}\text { Liquidity } \\
\text { risk }\end{array}$} & CDA & $\begin{array}{c}\text { Cash and Due held at other } \\
\text { depository institutions/Total } \\
\text { Assets }\end{array}$ & $+/-$ \\
\hline & LSI & $\begin{array}{l}\text { Total Trading securities and } \\
\text { Available for sale investment } \\
\text { securities/Total Assets }\end{array}$ & $+/-$ \\
\hline \multirow{2}{*}{$\begin{array}{c}\text { Capital } \\
\text { structure }\end{array}$} & CAP & Equity/Total Assets & $+/-$ \\
\hline & PE & Market price/Earnings per share & $+/-$ \\
\hline Bank size & SCALE & The logarithm of Total Assets & $+/-$ \\
\hline Efficiency & CIR & Total Costs/Total Income & - \\
\hline Ownership & Down1 & $\begin{array}{c}\text { Dummy }=1 \text { if bank is state's } \\
\text { ownership, }=0 \text { otherwise }\end{array}$ & - \\
\hline $\begin{array}{l}\text { GDP } \\
\text { growth rate }\end{array}$ & GDP & $\begin{array}{c}\text { Annual GDP growth rate of } \\
\text { Vietnam }\end{array}$ & + \\
\hline $\begin{array}{l}\text { Inflation } \\
\text { rate }\end{array}$ & INF & Vietnamese's inflation rate & $+/-$ \\
\hline Interest rate & LIBOR & Vietnamese's interest rate & $+/-$ \\
\hline
\end{tabular}
Down $1=1$ if bank is in other cases).

$\mathrm{GDP}_{t}$ is Vietnam's annual GDP growth rate at time t.

INF $_{t}$ is Vietnam's inflation rate at time $t$.

LIBOR $_{t}$ is Vietnam's interest rate at time t.

TABLE I: SUMMARY OF EMPIRICAL DATA

Table I summarizes the data used in econometric model and the expected coefficient sign. 


\section{The Result of Regression And AnAlysis}

\section{A. Data Description and Summary Statistics}

The research used annual data of 20 Vietnamese listed commercial banks over the period from 2011 to 2020 . For the bank's internal data, the statistics were taken from banks' financial statements. For macro-economic data, the data was collected from statistical reports and information published by World Bank (WB) and International Monetary Fund (IMF). Fortunately, all of the 20 banks' statistics were full and detailed, therefore the research can be conducted with strongly balanced panel data with 200 observations for the final sample.

TABLE II: SUMMARY STATISTICS

\begin{tabular}{ccccccc}
\hline \hline Variables & Symbol & $\mathrm{N}$ & Mean & $\begin{array}{c}\text { Std. } \\
\text { Dev. }\end{array}$ & Min & Max \\
\hline \multirow{3}{*}{ Profitability } & ROA & 200 & 0.008 & 0.006 & 0.00001 & 0.031 \\
& ROE & 200 & 0.106 & 0.073 & 0.0003 & 0.288 \\
& NIM & 200 & 0.032 & 0.014 & 0.003 & 0.095 \\
\hline Credit risk & NPL & 200 & 0.021 & 0.012 & 0.004 & 0.088 \\
& LDR & 200 & 0.867 & 0.192 & 0.372 & 1.805 \\
\hline $\begin{array}{c}\text { Liquidity } \\
\text { risk }\end{array}$ & CDA & 200 & 0.138 & 0.077 & 0.014 & 0.606 \\
Capital & CAP & 200 & 0.141 & 0.084 & 0 & 0.377 \\
structure & PE & 200 & 0.089 & 0.066 & 0.041 & 0.927 \\
\hline Bank size & SCALE & 200 & 18.836 & 1.038 & 16.589 & 21.140 \\
\hline Efficiency & CIR & 200 & 0.536 & 0.166 & 0.288 & 1.804 \\
\hline Ownership & Down1 & 200 & 0.9 & 0.301 & 0 & 1 \\
\hline $\begin{array}{c}\text { GDP } \\
\text { growth rate }\end{array}$ & GDP & 200 & 162.34 & 28.170 & 123.16 & 206.69 \\
\hline Inflation & INF & 200 & 5.483 & 4.929 & 0.631 & 18.678 \\
\hline rate & LIBOR & 200 & 4.083 & 2.946 & -3.552 & 7.322 \\
\hline \hline
\end{tabular}

The descriptive statistics of variables are shown in Table II. This table illustrates that the group of variables representing the profitability of Vietnamese listed commercial banks involve Return on Assets (ROA), Return on Equity (ROE), and Net Interest Margin (NIM). Three dependent variables are at the mean level with the value of $0.88 \%, 10.65 \%$, and $3.23 \%$, respectively.

Simultaneously, the Standard Deviations of the variables are fairly large, indicating that the variables were volatile over the research period. Particularly, ROA varies from $0.001 \%$ to $3.05 \%$ while ROE witnesses the fluctuation from $0.028 \%$ to $28.79 \%$. The range of NIM is from $0.28 \%$ to $9.45 \%$. Explaining for the volatility, (i) firstly, ongoing economic recession had a considerable influence on bank business operations; (ii) secondly, there were substantial differences amongst groups of banks in terms of capital structure, business capacity, and profitability.

According to explanatory variables, the means of LDR and CIR are very high, which are $86.7 \%$ and $53.65 \%$, respectively. LDR is even higher than the standard figure forced by Central Bank, which is $85 \%$ regarding the Circular 22. It reveals that credit extension and lending of Vietnamese commercial banks are one of the main activities of banks' businesses, which have been increasing considerably for years; therefore, they threaten the liquidity of banks. In addition, the index of CIR is quite high with a maximum of $180.35 \%$ and a minimum of $28.74 \%$. The reason for the difference is that the larger the bank's scale is, the less CIR bank has. Moreover, it depends on each bank and each period, specifically if a bank was investing in technology at that time, the costs were definitely higher than the income.

TABLE III: MATRIX CORRELATION

\begin{tabular}{|c|c|c|c|c|}
\hline & NPL & $\begin{array}{l}\text { LDR } \\
\end{array}$ & $\overline{\mathrm{CDA}}$ & LSI \\
\hline NPL & 1.000 & & & \\
\hline LDR & -0.2137 & 1.000 & & \\
\hline CDA & -0.0124 & -0.0378 & 1.000 & \\
\hline LSI & 0.0575 & -0.2720 & -0.2676 & 1.000 \\
\hline CAP & 0.0385 & 0.1368 & -0.0253 & 0.1013 \\
\hline PE & -0.0026 & -0.0583 & -0.0789 & -0.0467 \\
\hline SCALE & -0.2457 & 0.1799 & -0.1567 & -0.1125 \\
\hline CIR & 0.4037 & -0.3686 & 0.0378 & -0.1402 \\
\hline Down1 & 0.2129 & -0.1197 & -0.0817 & 0.1739 \\
\hline GDP & -0.3027 & 0.1720 & -0.2171 & -0.0942 \\
\hline INF & 0.1397 & 0.1372 & 0.5223 & -0.0517 \\
\hline \multirow[t]{2}{*}{ LIBOR } & -0.0661 & -0.1832 & -0.5061 & 0.0587 \\
\hline & CAP & $\overline{P P E}$ & SCALE & CIR \\
\hline CAP & 1.000 & & & \\
\hline PE & -0.0342 & 1.000 & & \\
\hline SCALE & -0.1871 & 0.0653 & 1.000 & \\
\hline CIR & -0.0759 & 0.0581 & -0.4109 & 1.000 \\
\hline Down1 & 0.0951 & 0.0252 & -0.5233 & 0.2547 \\
\hline GDP & -0.0030 & 0.0732 & 0.3825 & -0.1637 \\
\hline INF & 0.0650 & -0.0321 & -0.2472 & -0.1105 \\
\hline \multirow[t]{2}{*}{ LIBOR } & -0.0149 & -0.0003 & 0.1978 & 0.1351 \\
\hline & Down1 & GDP & INF & LIBOR \\
\hline Down1 & 1.000 & & & \\
\hline GDP & -0.0000 & 1.000 & & \\
\hline INF & -0.0000 & -0.6402 & 1.000 & \\
\hline LIBOR & -0.0000 & 0.5224 & -0.9277 & 1.000 \\
\hline
\end{tabular}

Table III depicts the matrix correlations of causal factors. High correlations within variables can lead to multicollinearity, which lowers the effectiveness of the estimation techniques. According to Kennedy (2008), significant correlations exist when the absolute values of the correlation coefficients exceed 0.80. Similarly, Anderson et al. (1990) hypothesized that multicollinearity appeared when the correlation coefficients were more than 0.7. Based on these standards, in Table III, only INF and LIBOR are significantly related (with the correlation coefficient of 0.9277), however, these two variables were taken originally from World Bank (WB), and both were macro-economic factors. Other pairs of independent variables having the linear correlation coefficient is less than 0.7 . Therefore, the research data does not appear the phenomenon of serious multicollinearity.

\begin{tabular}{ccc}
\multicolumn{3}{c}{ TABLE IV: THE RESULTS OF HAUSMAN TEST } \\
\hline \hline & Chi-S & Prob \\
\hline ROA & 11.97 & 0.2870 \\
ROE & 9.48 & 0.3944 \\
NIM & 1.61 & 0.9985 \\
\hline \hline
\end{tabular}

Table IV summarizes the findings of Hausman tests from a variety of models with three dependent variables (ROA, ROE, NIM, respectively). As demonstrated by the table, the random effects models (REM) are more efficient for all of three dependent variables with the prob-value of above $5 \%$. Hence, this study chooses REM to run the models. 


\section{B. The Result of Regression and Analysis}

Table V, VI, and VII show the results of regressions which explored the determinants of profitability of banks.

Table VIII, IX, and X show the summary of estimated results of profitability of banks.

TABLE V: SUMMARY OF RESULTS OF REGRESSIONS OF DETERMINANTS OF ROA (REM)

\begin{tabular}{ccccc}
\hline \hline ROA & Coef. & Std. Err. & $\mathbf{z}$ & $\mathbf{P}>|\mathbf{z}|$ \\
\hline NPL & 0.0314 & 0.0196 & 1.60 & 0.110 \\
LDR & 0.0053 & 0.0015 & 3.44 & 0.001 \\
CDA & 0.0046 & 0.0037 & 1.24 & 0.215 \\
LSI & 0.0081 & 0.0043 & 1.90 & 0.057 \\
& & & & \\
CAP & 0.0068 & 0.0040 & 1.73 & 0.084 \\
PE & $-2.33 e-08$ & $8.53 e-08$ & -0.27 & 0.785 \\
SCALE & 0.0010 & 0.0007 & 1.43 & 0.151 \\
CIR & -0.0154 & 0.0020 & -7.50 & 0.000 \\
Down1 & 0.0010 & 0.0017 & 0.58 & 0.561 \\
GDP & 0.00004 & 0.00002 & 2.64 & 0.008 \\
INF & 0.0003 & 0.0001 & 2.36 & 0.018 \\
LIBOR & 0.00007 & 0.0001 & 0.48 & 0.630 \\
cons & -0.0191 & 0.0128 & -1.49 & 0.163 \\
\hline \hline
\end{tabular}

TABLE VI: SUMMARY OF RESULTS OF REGRESSIONS OF DETERMINANTS OF ROE (REM)

\begin{tabular}{ccccc}
\hline \hline ROE & Coef. & Std. Err. & $\mathbf{z}$ & $\mathbf{P}>|\mathbf{z}|$ \\
\hline NPL & 0.0323 & 0.2170 & 1.53 & 0.126 \\
LDR & 0.0436 & 0.0181 & 2.41 & 0.016 \\
CDA & 0.0094 & 0.0466 & 0.20 & 0.839 \\
& & & & \\
LSI & 0.0556 & 0.0511 & 1.90 & 0.277 \\
& & & & \\
CAP & -0.2147 & 0.0480 & -4.47 & 0.000 \\
PE & $-3.89 \mathrm{e}-07$ & $1.02 \mathrm{e}-06$ & -0.38 & 0.704 \\
SCALE & 0.0227 & 0.0068 & 3.33 & 0.001 \\
CIR & -0.1713 & 0.0241 & -7.12 & 0.000 \\
Down1 & -0.0007 & 0.0221 & -0.03 & 0.974 \\
GDP & 0.0003 & 0.0002 & 1.64 & 0.102 \\
INF & 0.0014 & 0.0014 & 1.01 & 0.313 \\
LIBOR & -0.0016 & 0.0019 & -0.83 & 0.405 \\
cons & -0.3224 & 0.1349 & -2.39 & 0.017 \\
\hline \hline
\end{tabular}

TABLE VII: SUMMARY OF RESULTS OF REGRESSIONS OF DETERMINANTS OF NIM (REM)

\begin{tabular}{ccccc}
\hline \hline NIM & Coef. & Std. Err. & $\mathbf{z}$ & $\mathbf{P}>|\mathbf{z}|$ \\
\hline NPL & -0.0872 & 0.0413 & -2.11 & 0.035 \\
LDR & 0.0196 & 0.0038 & 5.19 & 0.000 \\
CDA & -0.0146 & 0.0086 & -1.70 & 0.090 \\
LSI & 0.0077 & 0.0086 & 0.90 & 0.367 \\
CAP & 0.0053 & 0.0051 & 1.05 & 0.295 \\
PE & $-1.77 \mathrm{e}-09$ & $1.65 \mathrm{e}-07$ & -0.01 & 0.991 \\
SCALE & 0.0019 & 0.0011 & -1.69 & 0.090 \\
CIR & -0.0126 & 0.0041 & -3.07 & 0.002 \\
Down1 & 0.0001 & 0.0028 & 0.04 & 0.970 \\
GDP & -0.00003 & 0.00003 & -0.74 & 0.458 \\
INF & 0.0005 & 0.0003 & 2.07 & 0.039 \\
LIBOR & 0.0004 & 0.0003 & 1.10 & 0.272 \\
cons & 0.0591 & 0.0229 & 2.58 & 0.010 \\
\hline \hline
\end{tabular}

\begin{tabular}{cccc}
\multicolumn{4}{c}{ TABLE IX: SuMMARY OF ESTIMATED RESULTS OF ROE } \\
\hline \hline Variables & Expected sign & $\begin{array}{c}\text { Estimated } \\
\text { sign }\end{array}$ & $\begin{array}{c}\text { Significant } \\
\text { level }\end{array}$ \\
\hline NPL & Negative & - & - \\
LDR & Negative & Positive & $5 \%$ \\
CDA & Positive/Negative & - & - \\
LSI & Positive/Negative & - & - \\
CAP & Positive/Negative & Negative & $5 \%$ \\
PE & Positive/Negative & - & - \\
SCALE & Positive/Negative & Positive & $5 \%$ \\
CIR & Negative & Negative & $5 \%$ \\
Down1 & Negative & - & - \\
GDP & Positive & Positive & $10 \%$ \\
INF & Positive/Negative & - & - \\
LIBOR & Positive/Negative & - & - \\
\hline \hline
\end{tabular}

\begin{tabular}{cccc}
\multicolumn{4}{c}{ TABLE X: SuMMARY OF ESTIMATED RESULTS OF NIM } \\
\hline \hline Variables & Expected sign & Estimated sign & $\begin{array}{c}\text { Significant } \\
\text { level }\end{array}$ \\
\hline NPL & Negative & Negative & $5 \%$ \\
LDR & Negative & Positive & $5 \%$ \\
CDA & Positive/Negative & Negative & $10 \%$ \\
LSI & Positive/Negative & - & - \\
CAP & Positive/Negative & - & - \\
PE & Positive/Negative & - & - \\
SCALE & Positive/Negative & Negative & $10 \%$ \\
CIR & Negative & Negative & $5 \%$ \\
Down1 & Negative & - & - \\
GDP & Positive & - & - \\
INF & Positive/Negative & Positive & $5 \%$ \\
LIBOR & Positive/Negative & - & - \\
\hline \hline
\end{tabular}

\section{FURTHER DISCUSSIONS}

A. The Effects of the Internal Banking Factors to the Profitability of Vietnamese Listed Commercial Banks

\section{1) Credit risk (NPL and $L D R$ )}

The study points out that the negative relation between NPL and NIM at a statistical significance of 5\% is similar to the expectation. However, it could not find any relation between NPL and ROA, or NPL and ROE. For the relation between NPL and NIM, it is obvious to understand that growing bad debts would force banks to raise reserve expenditures and also face a rise in credit risk, resulting in a fall in bank profit. Moreover, the total bad debts affect directly the net interest income of commercial banks (numerator of NIM) while the net income (numerator of ROA and ROE) depends on a wide of factors. This is the reason for 
the irrelevance between NPL and ROA, or NPL and ROE.

As expected, LDR has a negative impact on bank profitability. A commercial bank with a high LDR ratio means that the bank lends more, hence the higher credit risk. In addition, when the LDR ratio is high, the opportunity for credit growth based on deposits is no longer large, negatively affecting the profit growth of commercial banks. However, when running the model, the results are positive at a $5 \%$ significance level with both ROA, ROE, and NIM. This can be explained based on the short-term increase in assets. $90 \%$ of a bank's assets come from lending activities. Increased LDR means more lending so profits will be higher in the short term.

\section{2) Liquidity risk (CDA and LSI)}

Banks are also concerned about liquidity, in addition to credit risk. In principle, most researchers have found a negative relationship between bank liquidity and profit. The study figured out that CDA has a negative impact on NIM at a statistical significance of $10 \%$ that means the reliability is quite low. It can be explained that the more cash banks hold, the less liquid assets banks possess, and leading to the increase of the banks' liquidity risk. In addition, CDA does not impact both ROA and ROE.

According to the model, LSI only affects ROA in a positive way because the coefficient is 0.008138 . This is also the same as the theory of Bordeleau \& Graham 2010; Bourke 1989, which is explained in the literature review. On the other hand, when the banks hold lots of available for sale securities, it's easy for them to transfer into cash. Therefore, liquidity risk will decrease. Following this, the profitability of banks will go up.

All of these distinctions can be attributed to the fact that in Vietnam, during a period of severe liquidity as a result of the financial crisis, banks competed on interest rates and consistently outperformed the current interest rates for obtaining funds. As a result, the profitability of Vietnamese listed commercial banks has been distorted.

\section{3) Capital structure (CAP and PE)}

The regression indicates that the equity-to-total-assets ratio and ROA have a positive relationship. These findings are in line with those of Athanasoglou et al. (2008) and Pasiouras and Kosmidou (2008), who found that a high equity-to-totalassets ratio predicted strong profitability in emerging economies (2007). According to the hypothesis, lower-risk banks would benefit from transmitting their positive signals through a high equity-to-total-assets ratio when management and investors have asymmetric insight. Other scholars pointed out that in developing countries, the amount of equity held by banks was one of the primary concerns among depositors; as a result, banks with more equity would attract lower-yielding and more stable deposits, which would benefit their profits, particularly their return on assets (ROA). In the case of Vietnam commercial banks, these positive relationships also demonstrated that the franchise-value theory was correct. As a result of their great efficiency, efficient banks are increasingly choosing to maintain more stock in order to gain profit.

The changes in CAP ratio negatively impact ROE of Vietnamese listed commercial banks at a statistical significance of $5 \%$. These findings contradict the ideas that capital sufficiency and profitability have a positive relationship. In fact, Vietnamese banks use their strong capital adequacy to obtain lower-yielding and more steady deposits, but they are unable to increase their ROE. This might be described by Bensaid's research (1995). As a result, banks' approaches to coping with moral hazard have resulted in profit being reliant on unobserved heterogeneity choices. The study's findings could apply to the reality that the study interval coincided with a challenging moment for Vietnamese banks, when the country's growth rate was dropping, and businesses were hesitant to invest. This, along with a significant NPL rate, resulted in a considerable reduction in bank ROE from 2011 to 2020 as compared to the prior period. According to the data, the average ROE of the banks in the sample is only 10.65 percent, compared to 16.79 percent in the prior period from 2006 to 2010. Meanwhile, as demonstrated in the model, new regulations (Circular 13/2010/CIR-SBV and Circular 36/2014/CIR-SBV) forcing banks to boost CAR from $8 \%$ to $9 \%$ may induce adverse relations.

$\mathrm{PE}$ has no effect on any long-term profitability ratios since this indicator is temporary. A high PE means the bank is at the bottom of the business cycle. Profits are down but it is only in the short term. When entering a new cycle, commercial banks start operating more efficiently, the EPS (profit) increases, the PE decreases. The continuous change of $\mathrm{PE}$ in the long-term will be less volatile, so when running the model, PE will not be statistically significant as a whole.

\section{4) Bank size (SCALE)}

At the statistical significance of $5 \%$, the estimation findings show a favourable association between the number of Vietnam banks and their ROE. The estimated coefficient of scale with ROE is 0.227232 which means that when commercial banks grow $5 \%$ of total assets, ROE increases by 0.227232 points. The research concluded no statically meaningful connections between the bank size and profitability in models using ROA or NIM as dependent variables. The result of a positive effect in the case of ROE and not statistically significant in the case of ROA and NIM implies that the bank's total asset growth is equal to the growth in liabilities. Liabilities growth helps to increase the net income, thereby resulting in an increase in ROE figures, proving that the bank's choice of investment has a good return. Therefore, the bank's growth in scale does greatly enhance profitability.

At the statistical significance of $10 \%$, only on the NIM model that scale is determined positively related to the profitability of banks. Unfortunately, the paper could not discover such relationships in models using ROA and ROE as dependent variables. The study by Berger et al. (2008) may explain the ambiguous influence of the variable size on bank profitability. According to the study, this is attributable to the group effects of governmental commercial banks. In Vietnam, state-owned banks that government holds the major shares are also the biggest banks. However, such banks' profitability is volatile and has been deteriorating, in part owing to incentives to lend to unproductive state enterprises. The estimation outcomes for variable SCALE are further attributed to the fact that throughout the past, small banks and freshly formed banks were prone to concentrate on the rising 
scale while neglecting the value of loan portfolios, severely hampering their profitability.

\section{5) Efficiency (CIR)}

At a statistical significance of 5\%, the cost to income was shown to be adversely associated with bank profitability for all models including ROA, ROE, and NIM as dependent variables, which was consistent with previous research by Molyneaux and Thornton (1992), Athanasoglou et al (2006). This result shows that commercial banks with good cost management will achieve high operating efficiency and win big profits, in other words, achieve high profitability. Similar findings were discovered by Athanasoglou et al. (2008). In Vietnam, during periods of dramatic growth, most banks' profits rise substantially, but their associated costs tend to rise as well. Only institution that effectively manages its costs can keep costs rising at a slower rate than revenue, ensuring profit earning.

\section{6) Ownership structure (Down1)}

The findings of regressions revealed that there is no clinically important correlation between state ownership and Vietnamese bank profitability. Although state-owned banks are guaranteed profitability, non-state-owned commercial banks still have their policies to ensure profitability without the need for management of the government.

B. The Effects of the Macroeconomic Factors to the Profitability of Vietnamese Listed Commercial Banks

\section{1) GDP growth rate (GDP)}

GDP is expected to have a positive correlation with the profitability of the bank in this paper, similar to the finding of Pasiouras and Kosmidou (2007).

After running the model, we find that the coefficient between GDP and ROA is 0.0000474 (at the 5\% significant level). It shows that GDP moves in the same direction as ROA. It's the same as ROE at the $10 \%$ significant level.

GDP growth has a positive impact on both ROA and ROE of commercial banks, although the ROE case is not statistically significant (5\%). When GDP grows, it is often accompanied by an increase in aggregate demand in the economy. Vietnamese commercial banks play a key role in financing the economy, thereby benefiting through the growth of demand for traditional products such as credit and capital mobilization. In addition, they also benefit from the growth in demand for services such as payments, guarantees, credit commitments, and other non-interest activities. This result is similar to the results of Pasiouras and Kosmidou (2007); Kosmidou and Pasiouras (2008); Sufian and Habibullah (2009b, 2012); Chronopoulos (2015); Caporale (2017); Chen (2018).

\section{2) Inflation rate (INF)}

The coefficients of Inflation rate (INF) are positive for both ROA and NIM of commercial banks at a statistical significance of $5 \%$, whereas ROE witnesses no effects of INF. Perry (1992); Athanasoglou et al. (2008) show that the effect of inflation is only positive in the case of "predictable" inflation. A transparent and clear inflation control policy helps commercial banks gain benefits from adjusting credit and deposit interest rates and vice versa. In recent years, the policy of controlling inflation has been increasingly publicized by the State Bank of Vietnam with its objectives and tools. Thereby, it brings benefits to commercial banks in managing their interest rates. This result is similar to the results of Kosmidou and Pasiouras (2008); Sufian (2011); Sufian and Habibullah (2012); Caporale et al. (2017).

\section{3) Interest rate (LIBOR)}

At the statistical significance of $5 \%$, the results of regressions showed that there is no statistically significant relationship between the interest rate and the profitability of Vietnamese commercial banks. When dealing with liquidity risk, commercial banks would borrow from other commercial banks before requesting support from the Central Bank and LIBOR interest rate would be used in this circumstance. LIBOR are usually applied in short-term and changes continuously. Therefore, in short term, LIBOR interest rate doesn't have any influence on ROA, ROE, and NIM, or simply put, on the profitability of Vietnamese commercial banks.

\section{RECOMMENDATIONS AND CONCLUSION}

Through the results of the models, it can be concluded that the bank's profit is affected by two macro-economic factors and the internal factors of the bank. In which, LDR and CIR have the strongest impact, because they affect ROA, ROE, and NIM at 5\% significance level. The loan-to-deposit ratio has a positive relationship, showing that short-term lending activities of banks are being promoted, leading to an increase in interest income and total assets of the bank. In addition, the Cost to income index has an inverse relationship, showing that the bank is cutting costs during this period.

\section{A. Recommendations for Commercial Banks}

\section{1) Reducing costs}

According to the research result, operating costs have the strongest and most negative impact on profitability. As a result, commercial banks should implement cost-cutting initiatives. One solution is to create MIS (Management information system) data system to extract detailed profitcost details for each type of activity, thereby measuring the impact of various types of costs on commercial bank profitability and detecting the types of costs that have the most negative impact on commercial bank operations. Some commercial banks have implemented KPI (Key Performance Index) system to assess the working efficiency of employees, thereby, having a basis for paying salaries and other incomes for employees.

\section{2) Reducing liquidity risk and credit risk}

The negative impact of liquidity risk implies that in the process of credit growth, commercial banks need to ensure the source of capital mobilization to balance and ensure the necessary liquidity. The lack of liquidity often leads to a high cost of goods, which will adversely affect the business performance of commercial banks. Similarly, the negative impact of credit risk implies that commercial banks need to improve the credit appraisal and approval process as well as balance the credit growth target and credit risk.

\section{B. Recommendations for Central Bank}

An increase in bank size can reduce a bank's profitability when investments are not performing well. Commercial 
banks depositing money at other credit institutions or state banks will make this money not profitable, affecting the bank's profit. Therefore, the central bank should only regulate a certain number of deposits, enabling commercial banks to use the money to invest in other profitable activities. From there, profitability efficiency will increase.

In addition to encouraging profitable investment activities, the central bank should also improve the system of circulars and regulations following Basel standards and international accounting standards. Thus, the operation of commercial banks will be less risky and more efficient. To avoid inflation affecting the profitability of commercial banks in general, the central bank needs to have appropriate policies to keep inflation at a moderate level.

\section{REFERENCES}

Abreu, M., \& Mendes, V. (2001, May). Commercial bank interest margins and profitability: evidence for some EU countries. In Pan-European Conference Jointly Organised by the IEFS-UK \& University of Macedonia Economic \& Social Sciences, Thessaloniki, Greece, May (17-20).

Allen, F., Carletti, E., \& Marquez, R. (2011). Credit market competition and capital regulation. Review of Financial Studies, 24(4), 983-1018.

Athanasoglou, P. P., Brissimis, S. N., \& Delis, M. D. (2008). Bank-specific, industry-specific and macroeconomic determinants of bank profitability. Journal of international financial Markets, Institutions and Money, 18(2), 121-136.

Bensaid, B., Pages, H., \& Rochet, J. C. (1996). Efficient regulation of banks' solvency. Institutd'economieindustrielle, Universitédes Sciences sociales de Toulouse.

Berger, A. N. (1995). The profit-structure relationship in banking-tests of market-power and efficient-structure hypotheses. Journal of Money, Credit and Banking, 27(2), 404-431.

Berger, A. N., DeYoung, R., Flannery, M. J., Lee, D., \& Öztekin, Ö. (2008). How do large banking organizations manage their capital ratios? Journal of Financial Services Research, 34(2-3), 123-149.

Boahene, S. H., Dasah, J., \& Agyei, S. K. (2012). Credit risk and profitability of selected banks in Ghana. Research Journal of finance and accounting, 3(7), 6-14.

Bordeleau, E., \& Graham, C. (2010). The impact of liquidity on bank profitability. Bank of Canada working paper.

Bourke, P. (1989). Concentration and other determinants of bank profitability in Europe, North America and Australia. Journal of Banking \& Finance, 13(1), 65-79.

Boyd, J., \& Runkle, D. (2000). Size and performance of banking firms: Testing the predictions of theory. Journal of Menetary Economics, 31(1), 47-67.

Demirgüç-Kunt, A., \& Huizinga, H. (1999). Determinants of commercial bank interest margins and profitability: some international evidence. The World Bank Economic Review, 13(2), 379-408.

Demirgüç-Kunt, A., \& Huizinga, H. (2000). Financial structure and bank profitability. World Bank Mimeo.

Duong Thuy Nguyen., Huyen Thanh Ta., Huong Thi Diem Nguyen. (2018). 'What Determines the Profitability of Vietnam Commercial Banks?'. Banking Academy of Vietnam, Vietnam.

Emery, J. T. (1971). Risk, return, and the morphology of commercial banking. Journal of Financial and Quantitative Analysis, 6(02), 763776.

Goddard, J. A., Molyneux, P., \& Wilson, J. O. (2004). Dynamics of growth and profitability in banking. Journal of Money, Credit, and Banking, 36(6), 1069-1090.

Heggestad, A. A. (1977). Market structure, risk and profitability in commercial banking. The Journal of Finance, 32(4), 1207-1216.

Kasman, A., Tunc, G., Vardar, G., \& Okan, B. (2010). Consolidation and commercial bank net interest margins: Evidence from the old and new European Union members and candidate countries. Economic Modelling, 27(3), 648-655.

Kieu, H. T., \& Phan, M. H. (2014). Ownership structure and efficiency of commercial banks. Banking magazine.

Kithinji, A. M. (2010). Credit Risk Management and Profitability of Commercial Banks in Kenya. School of Business, University of Nairobi, Nairobi.

Kosak, M., \& Cok, M. (2008). Ownership Structure and Profitability of the
Banking Sector: The Evidence from the SEE-6 Region. Journal of Economics and Business, 26(1), 93-122.

Marcia, M. C., Lin, G., Shahria, K., \& Hassan, T. (2010). The impact of state ownership on performance differences in privately-owned versus stateowned banks: An international comparison. Journal of Financial Intermediation, 19, 74-94.

Mboka, T. M. (2013). Effects of macro-economic variables on nonperforming loans of commercial banks in Kenya (Doctoral dissertation, University of Nairobi)

Molyneux, P., \& Thornton, J. (1992). Determinants of European bank profitability: A note. Journal of banking \& Finance, 16(6), 1173-1178.

Nicolae, P., Bogdan, C., \& Iulian, I. (2015). Determinants of Banks' Profitability: Evidence from EU 27 Banking Systems.

Petter S. Rose., Sylvia C. Hudgins., (2013). Bank Management \& Financial Services (3rd ed., pp. 181-187.)

Revell, J. (1979). Inflation \& Financial Institutions. Financial Times Limited.

Short, B. K. (1979). The relation between commercial bank profit rates and banking concentration in Canada, Western Europe, and Japan. Journal of Banking \& Finance, 3(3), 209-219.

Trujillo-Ponce, A. (2013). What determines the profitability of banks? Evidence from Spain. Accounting \& Finance, 53(2), 561-586.

Tu D. Q. Le., \& Dat T. Nguyen. (2020). Capital Structure and Bank Profitability in Vietnam: A Quantile Regression Approach. Journal of Risk and Financial Management.

Vernon, J. R. (1971). Separation of Ownership and Control and Profit Rates, the Evidence from Banking: Comment. Journal of Financial and Quantitative Analysis, 6(1), 615-622.

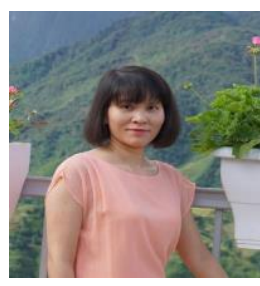

Hoai Linh Do is an Associate Professor and Vice Head of Commercial Banking Department, School of Banking and Finance, National Economics University, Vietnam. She teaches Banking Management and Personal Finance subjects.

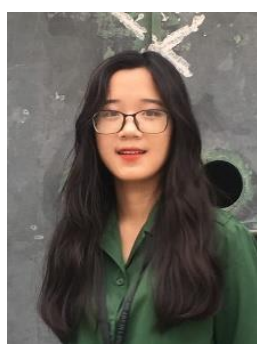

Hong Lieu Le was born on July $6^{\text {th }}, 2000$ in Hanoi, Vietnam. From 2015 to 2018, she studied at Chu Van An National High School for the Gifted with a specialization in literature. From 2018 to now, she is majoring in Finance and Banking at National Economics University, Vietnam (NEU).

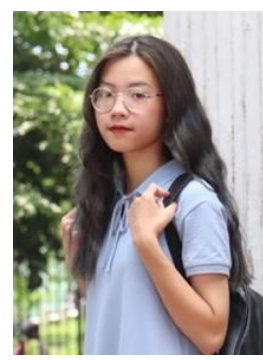

Nguyen Linh Dan Le was born on November $11^{\text {th }}$, 2000 in Hanoi, Vietnam. From 2015 to 2018, she studied at Chu Van A National High School for the Gifted with excellent grades. From 2018 to now, she is a student in Finance and Banking at National Economics University, Vietnam (NEU). She is one of the honour students studying in the Advanced Education Programs at NEU.

She has experiences in finance field as a business customer relationship management assistant in Vietnam Prosperity Joint Stock Commercial Bank from December 2020 to May 2021 in Hanoi, Vietnam. Ever since, she has been an excellent employee in VPS Securities Joint Stock Company as a business support collaborator in Hanoi, Vietnam. 